\title{
A NEW BIPV BRICK PAVING THE WAY TO ENERGY-GENERATING CONCRETE FAÇADE
}

\author{
MATTHIEU HORGNIES, ISABELLE DUBOIS-BRUGGER \& FABIENNE LEGRAND \\ LafargeHolcim R\&D, 38291 St Quentin-Fallavier, France
}

\begin{abstract}
A significant part of the world global energy consumption is used to heat and/or and cool buildings. While insulation regulations are gradually strengthened in several counties, decentralized energy generation (such as the building-integrated photovoltaic, BIPV) is more and more considered as a strong lever to improve the energy self-consumption of the building and mitigate the impact of the large urban areas on climate change. Our researches aim to promote new photovoltaic systems on the concretebased envelop (more especially by the way of an aesthetical cladding system) in order to increase the value of residential and office buildings. A durable multi-layer's system based on ultra-high performance fibre-reinforced concrete (UHPFRC), specific structural adhesives and solar cells (or films) has been developed to be directly cladded on the façades of buildings. After demonstrating the durability of the multilayers using different aging tests in laboratory, the production of a fully integrated cladding system, based on concrete, has been demonstrated in pre-cast plant in 2017. The next step, under progress, is the building of an outdoor demonstrator, which will be helpful to give proofs of durability under weathering and monitor the efficiency the PV façade panels for different sun exposures over several years.
\end{abstract}

Keywords: BIPV, adhesion, durability, photovoltaic, concrete, interface, façade, demonstrator.

\section{INTRODUCTION}

A part of the global energy consumption is used for heating and cooling buildings and insulation regulations are gradually strengthened all over the world. Furthermore, decentralized energy generation in buildings is considered as one of the main levers to mitigate the impact of buildings on climate change, improve the use of national power grids and reduce the operating expenses for owners [1]-[4]. Consequently, promoting the concretebased envelop by adding a gainful function based on the production of electricity tends to increase the value to the residential and office buildings [5]-[10]. The installation of photovoltaics on several vertical façades of buildings could also partially answer the seasonal mismatch between the production and the consumption of electricity. Indeed, different vertical exposures would enlarge the production of photovoltaic electricity over longer periods of time (earlier/later during day, in Spring and Autumn), than in case of photovoltaics only installed on the roof, facing the sun direction in Summer (to maximize the electricity production, but over a restrained range of time).

Our researches have been undertaken by using concrete as a direct support of the solar cells/films by the way of an aesthetical cladding system. Consequently, we have mainly focused on the use of ultra-high performance fibre-reinforced concrete (UHPFRC), which is known to present a smooth and durable surface due to its mix-design and specific interactions with the formworks and demoulding agents [11]-[13]. A patented process (already described in a previous paper [14]) aims to manufacture a multi-layer's composite material based on UHPFRC, specific structural adhesives and solar cells (or films).

In this paper, we will overview the several steps of development done during the last two years and/or always in progress. After summarizing the different tests of durability done on the interface between concrete, glue and photovoltaic devices, we will present the results from the first tests of production of integrated façade panels, undertaken in a pre-cast plant 
in 2017. Finally, we will detail the next step under progress, with the building of a first outdoor demonstrator near Lyon (France), in order to give proofs of durability under weathering, and to monitor their efficiency over several years.

\section{DESCRIPTION OF THE PROCESS OF INTEGRATION}

The process of integration of the PV cells on concrete and the composition of the raw materials (concrete, glue, PV cells) were already detailed in a previous paper [14]. They can be quickly summarized in successive steps:

- A layer of glue or an adhesive tape is applied on the backside of the PV cell/film, which is deposited at the bottom of the casting mould.

- The fresh mix-design of concrete is poured into this mould in order to coat the layer of glue/adhesive.

- After about 18 hours, the concrete has hardened and all the multilayers system can be removed from the mould.

The Fig. 1 shows some pictures of the first prototype (curved shape of $3 \mathrm{~m}$ length) done using ultra-high performances fibres concrete, an adhesive tape composed of polyisoprenepolyisobutylene and a flexible PV film (composed of a-silicon).

\section{CHARACTERISATION OF THE INTERFACE AND DURABILITY}

The morphology and the composition of polished cross-sections of the multilayer composing the panels were characterized by scanning electron microscope (SEM FEG Quanta 400 from FEI Company, accelerating voltage of $15 \mathrm{keV}$ and current intensity of $1 \mathrm{nA}$ ) and Energydispersive X-ray spectroscopy (EDS, XFlash ${ }^{\circledR}-100$ SDD detector from Bruker). As detailed by Fig. 2, no particular air void was detected at the interface between concrete, epoxy-based glue and the backside of the PV cell. Moreover, the hydrated cement paste containing limestone-based filler and sand is characteristic of the mix-design of the concrete. As detected by EDS, the epoxy-based glue was composed of fine filler made of magnesium sulphate and barium sulphate. According to the multiple analyses done, the thickness of the layer of glue was estimated to $600 \mu \mathrm{m}+/-300 \mu \mathrm{m}$.

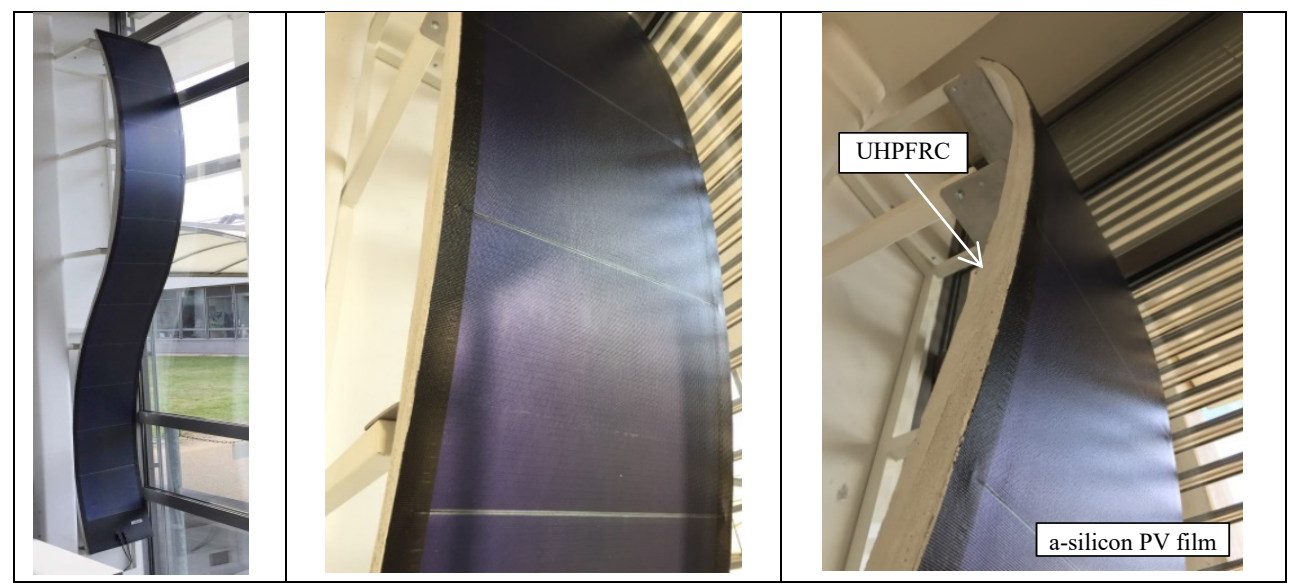

Figure 1: First prototype (curved panel) based on UHPFRC integrating a flexible $3 \mathrm{~m}$-long photovoltaic film. 


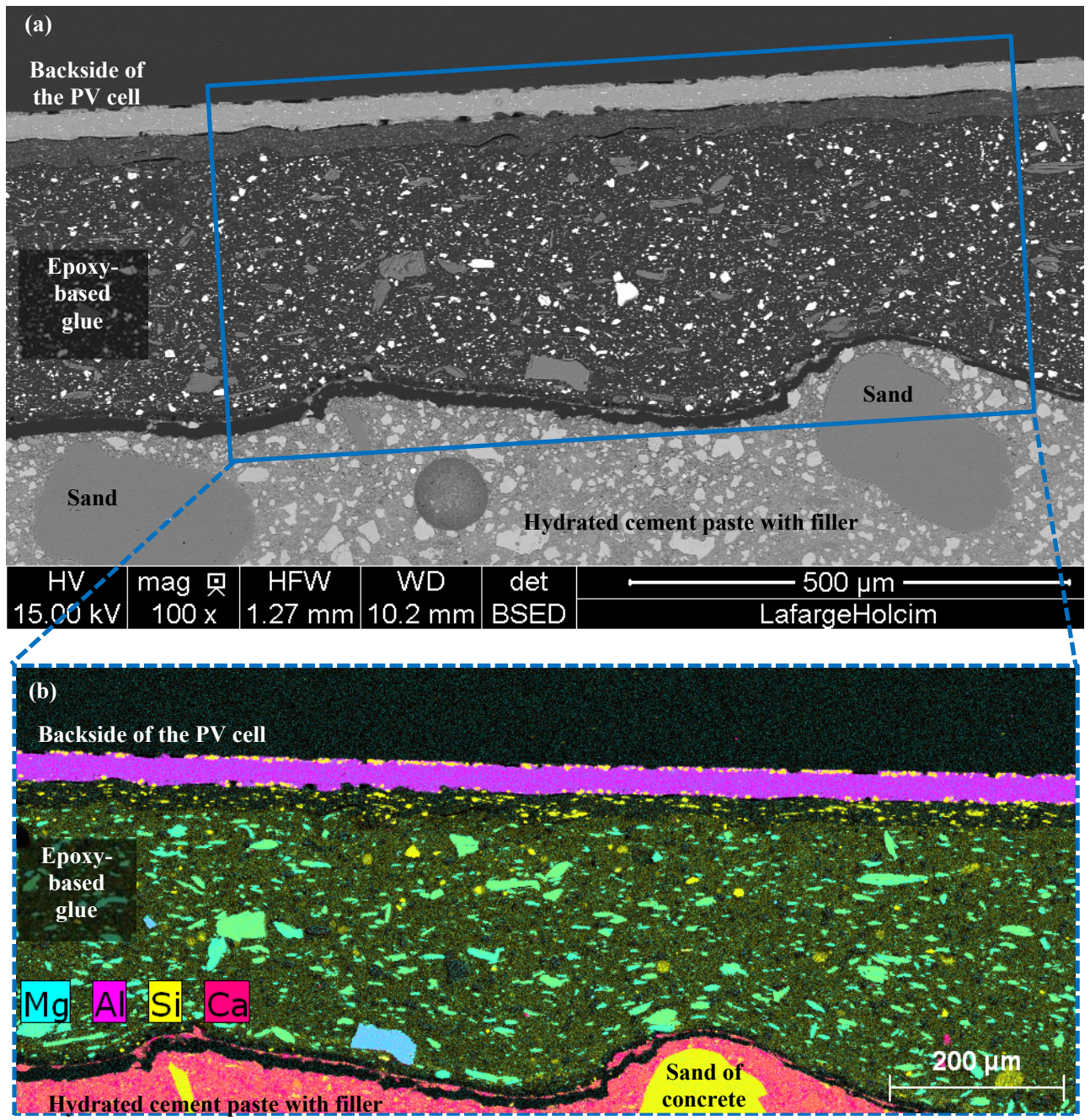

Figure 2: (a) Polished cross-section of the interface between concrete, epoxy-based glue and the backside of a PV cell: observed by SEM; (b) Analysed by EDS.

The adhesion and the durability of the interface were studied using the pulling out method (using a dynamometer) and several accelerated aging methodologies [14]:

- Continuous storage in a condensation chamber $\left(60^{\circ} \mathrm{C} / 100 \%\right.$ relative humidity),

- Storage in a UV-rays chamber $\left(4 \mathrm{~h}\right.$ at $60^{\circ} \mathrm{C}$ with $\mathrm{UV}$, followed by $4 \mathrm{~h}$ at $50^{\circ} \mathrm{C}$ without UV),

- $\quad$ Storage in a freeze-thaw chamber (cycling between $+9^{\circ} \mathrm{C}$ and $-18^{\circ} \mathrm{C}$ ).

According to the tests performed (Fig. 3, [14]), the best results in terms of durability were obtained using an epoxy-based glue or an adhesive tape made of polyisoprenepolyisobutylene (until 800 freeze-thaw cycles and until 9 months of UV aging/condensation 
tests without any debonding issue). Moreover, it was possible to establish the best range of roughness for the backside of the PV cells/films making possible the best adhesion with the layer of glue (values of adhesion until $1.18 \mathrm{MPa}$ were obtained).

\section{TESTS OF INTEGRATION IN PRECAST PLANT}

We decided to conduct tests in precast plant to give first proofs of industrialisation of the new PV system based on UHPFRC. The main goals were to bring a high architectural quality to the façade panels without any significant modifications of the process line. More than 30 photovoltaic façade panels were then produced during two trials performed in February and October 2017.

As shown in Fig. 4, the dimensions of each façade panel were about $2.4 \mathrm{~m}$ length by $1.2 \mathrm{~m}$ width, incorporating about $1.5 \mathrm{~m}^{2}$ of PV films (covering about $50 \%$ of the area). As shown in Fig. 4(d) (in red), the electrical connectors (junction boxes) emerge directly on the backside of the concrete-based panels, without any cable visible on its front-side.

These trials also established that this new type of photovoltaic façade panels were able to resist against water during the several post-treatments done after hardening of concrete (polishing, cleaning, cutting steps), showing a nice and smooth aesthetic for a minimum of thickness of the façade panels (less than $20 \mathrm{~mm}$ ).
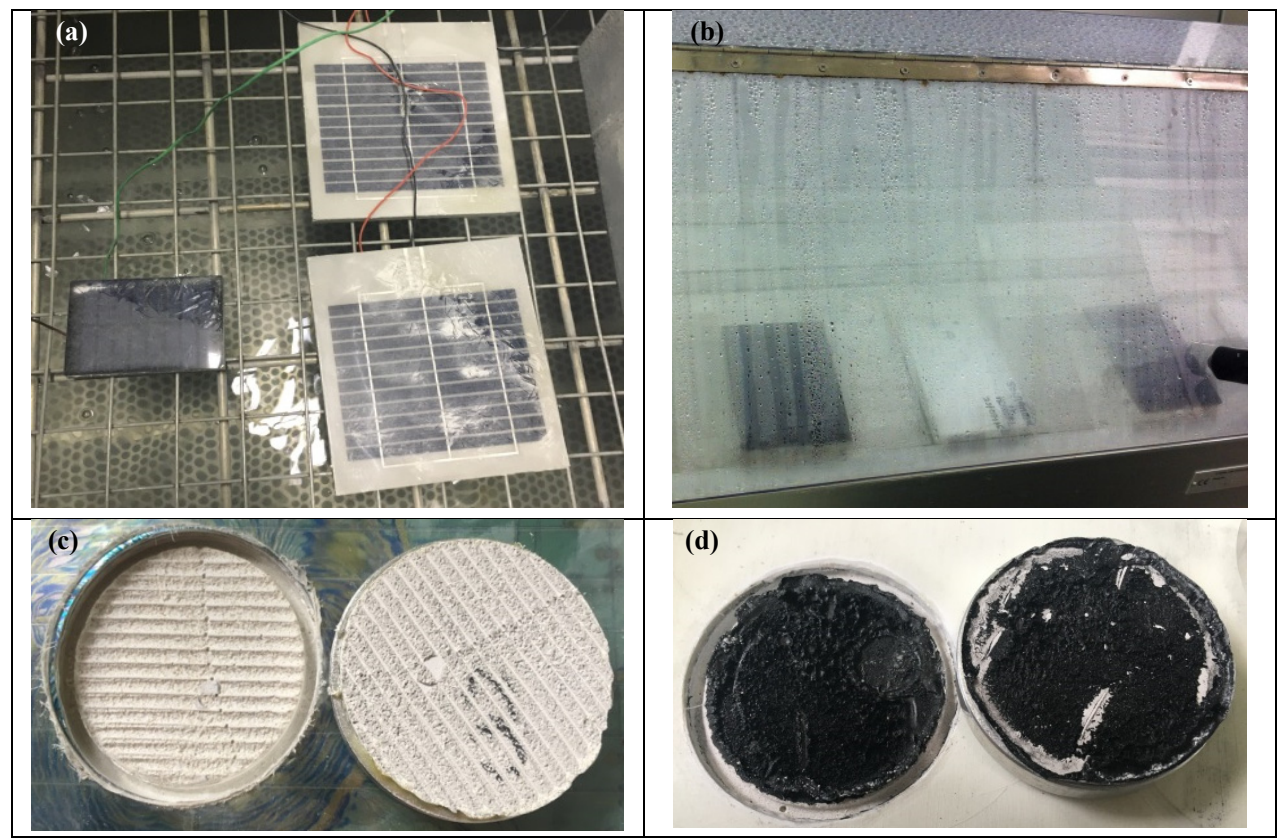

Figure 3: (a) Some durability tests and pictures of the interfaces after pulling out (adhesion) tests: samples covered by ice during freeze-thaw test; (b) Samples in the condensation chamber; (c) Interface after the pulling out test with debonding between epoxy-glue layer and concrete, (d) Interface with debonding into the adhesive tape. 

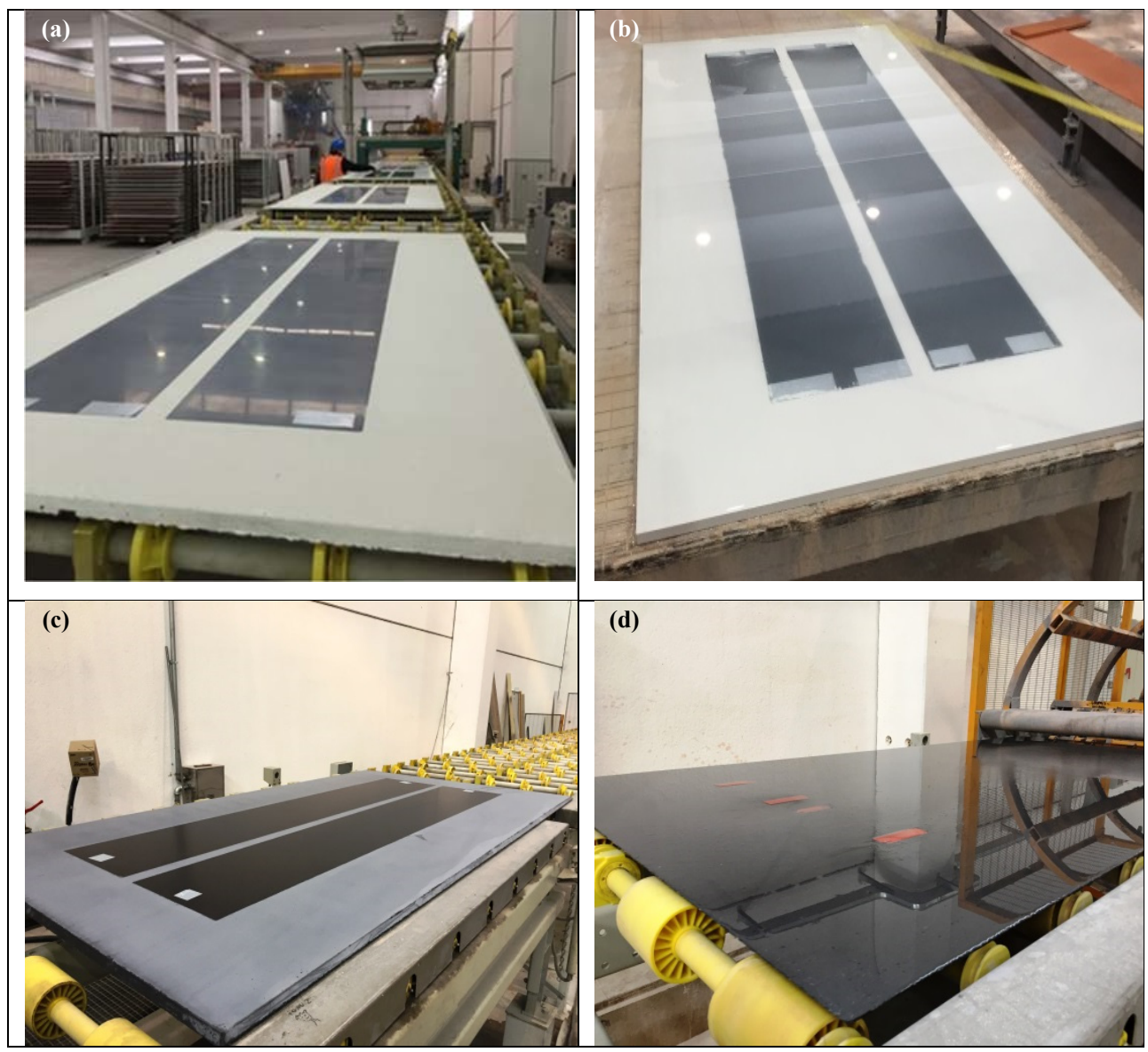

Figure 4: (a), (b), (c) Façade panels based on UHPFRC and integrating PV films; (d) Frontside backside showing the outputs for the electrical devices (in red).

\section{DEMONSTRATOR AND PROSPECTIVE ACTIONS}

A first demonstrator of the entire cladding system is scheduled in 2018 near Lyon (France), using some of the PV façade panels produced in precast plant. About 10 façade panels (maybe until 14), showing a total of $13 \mathrm{~m}^{2}$ of photovoltaic area, fully integrated on $25 \mathrm{~m}^{2}$ area of concrete-based façade panels, are expected to be installed on a main structure (5.0m length, $2.5 \mathrm{~m}$ width, $2.8 \mathrm{~m}$ height) already built in 2017 .

As shown in Fig. 5, the PV façade panels will be cladded on at least 3 walls of the structure (facing respectively to East, South and West). Moreover, no cable is expected to be visible on the front-side, keeping as more aesthetical as possible the façades of the building. The main goal of this demonstrator is to confirm that the installation of the PV façade panels based on UHPFRC is possible without any complex modifications and without over-costs. The other goals are to give proofs of durability under weathering, and to monitor their efficiency over several years and under different sun exposures. 


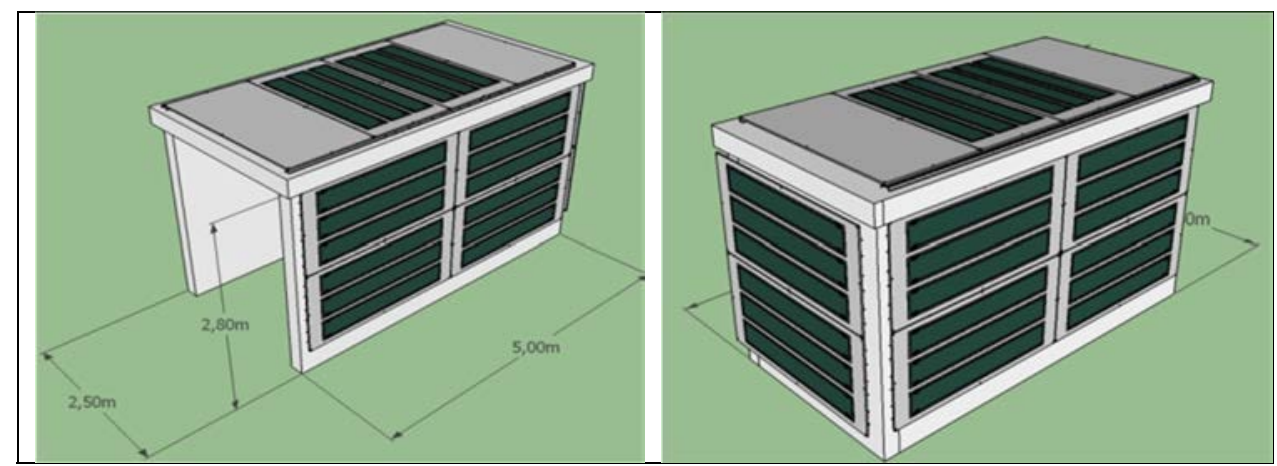

Figure 5: Demonstrator scheduled in 2018, composed of about $25 \mathrm{~m}^{2}$ of PV facade panels made of UHPFRC. The main vertical façades will be exposed to East, South and West in order to monitor the aging and the efficiency of the PV films according to the sun exposure.

\section{CONCLUSIONS}

New solutions about Building Integrated Photovoltaic are necessary to answer the growing needs for a decentralized generation of renewable energies. Complementary to the PV installed on the roof, the development of aesthetical photovoltaic façade could be an opportunity to: (i) provide more energy to heat or cool residential and office buildings, (ii) enlarge the production of electricity over longer periods of time (all along the day and year), (iii) minimize the consumption of fossil fuels, and (iv) reduce the impact of urban areas on the climate changes.

In this study, we developed a cladding system based on ultra-high-performance fibrereinforced concrete panels integrating PV films. After establishing the durability of the multilayers system using accelerating tests in laboratory, we showed the first proofs of industrialisation in 2017 by doing trials in precast plant and by producing more than 30 façade panels (covered at about $50 \%$ by the photovoltaic devices).

The next step is the building of a demonstrator composed of $25 \mathrm{~m}^{2}$ of façade panels, which is scheduled for 2018. This demonstrator will be helpful to give proofs of durability under weathering, but also to monitor the efficiency the PV films for different sun exposures (EastSouth-West).

\section{ACKNOWLEDGMENT}

The authors would like to thank Alexander Eisenhauer (LafargeHolcim) for his helpful work regarding the innovation and marketing strategies.

\section{REFERENCES}

[1] Alnaser, N.W., Building integrated renewable energy to achieve zero emission in Bahrain. Energy and Buildings, 93, pp. 32-39, 2015.

DOI: 10.1016/j.enbuild.2015.01.022.

[2] El Gindi, S., Abdin, A.R. \& Hassan, A., Building integrated photovoltaic retrofitting in office buildings. Energy Procedia, 115, pp. 239-252, 2017.

DOI: 10.1016/j.egypro.2017.05.022.

[3] Sorgato, M.J., Schneider, K. \& Rüther, R., Technical and economic evaluation of thinfilm CdTe building integrated photovoltaics (BIPV) replacing façade and rooftop 
materials in office buildings in a warm and sunny climate. Renewable Energy, 118, pp. 84-98, 2018. DOI: 10.1016/j.renene.2017.10.091.

[4] Curtius, H.C., The adoption of building-integrated photovoltaics: barriers and facilitators. Renewable Energy, 126, pp. 783-790, 2018.

DOI: 10.1016/j.renene.2018.04.001.

[5] Ceron, I., Caamaño-Martin, E. \& Neila, F.J., 'State-of-the-art' of building integrated photovoltaic products. Renewable Energy, 58, pp. 127-133, 2013.

DOI: 10.1016/j.renene.2013.02.013.

[6] Cronemberger, J., Almagro Corpas, M., Ceron, I., Caamaño-Martin, E. \& Vega Sanchez, S., BIPV technology application: highlighting advances, tendencies and solutions through solar Decathlon Europe houses. Energy and Buildings, 83, pp. 4456, 2014. DOI: 10.1016/j.enbuild.2014.03.079.

[7] Polo Lopez, C., Frontini, F., Bonomo, P. \& Scognamiglio, A., PV and façade systems for the building skin. Analysis of design effectiveness and technological features. Proceedings of the Twenty-ninth European Photovoltaic Solar Energy Conference and Exhibition, Amsterdam, 2014.

[8] Verberne, G. et al., BIPV products for façades and roofs: a market analysis. Proceedings of the Twenty-ninth European Photovoltaic Solar Energy Conference and Exhibition, Amsterdam, 2014.

[9] Shukla, A.K., Sudhakar, K. \& Baredar, P., A comprehensive review on design of building integrated photovoltaic system. Energy and Buildings, 128, pp. 99-110, 2016. DOI: 10.1016/j.enbuild.2016.06.077.

[10] Evola, G. \& Margani, G., Renovation of apartment blocks with BIPV: energy and economic evaluation in temperate climate. Energy and Buildings, 130, pp. 794-810, 2016. DOI: 10.1016/j.enbuild.2016.08.085.

[11] Gueit, E., Darque-Ceretti, E., Tintillier, P. \& Horgnies, M., Surfactant-induced growth of calcium hydroxide coating at the concrete surface. Journal of Coating Technology and Research, 9(3), pp. 337-346, 2012. DOI: 10.1007/s11998-011-9368-4.

[12] Horgnies, M. \& Chen, J.J., Superhydrophobic concrete surfaces with integrated microtexture. Cement and Concrete Composites, 52, pp. 81-90, 2014. DOI: 10.1016/j.cemconcomp.2014.05.010.

[13] Horgnies, M., Darque-Ceretti, E., Gueit, E. \& Aucouturier, M., Characterisation of the variations of tint and the adhesion of pigments onto the surface of mortar. Construction and Building Materials, 94, pp. 380-386, 2015.

DOI: 10.1016/j.conbuildmat.2015.07.083.

[14] Horgnies, M., Legrand, F., Bonnet, E. \& Dubois-Brugger, I., Study of the interface and durability of the adhesion between photovoltaic cells and concrete-based façade panels. WIT Transactions on Engineering Sciences: Materials and Contact Characterisation VIII, WIT Press, 116, pp. 171-179, 2017. 